\title{
Analisis Ketidakpastian Dalam Memanfaatkan Lahan Pertanian Di Desa Sukasari Kaler Kecamatan Argapura Majalengka
}

\author{
Sudrajat ${ }^{1}$ \\ Faculty of Geography, Universitas Gadjah Mada, Indonesia ${ }^{1}$ \\ Email Koresponden:sdrajat@ugm.ac.id
}

Diterima: Januari 2018 /Disetujui: Februari 2018 / Publikasi online: Maret 2018

(C) 2018 Fakultas Geografi UGM dan Ikatan Geograf Indonesia (IGI)

\begin{abstract}
Abstrak Petani dalam memanfaatkan lahan pertanian selalu berhadapan dengan ketidakpastian. Di sisi lain petani juga harus mempertimbangkan berbagai jenis komoditi yang akan diusahakan agar tidak gagal panen. Berdasarkan hal tersebut maka penelitian ini dilakukan dengan tujuan: (1) mengindentifikasi jenis ketidakpastian yang sering dihadapi petani dalam memanfaatkan lahan pertanian; dan (2) menganalisis pengaruh ketidakpastian terhadap pertimbangan petani dalam menentukan jenis komoditi yang akan diusahakan. Data yang dikumpulkan terdiri dari data primer dan data sekunder. Data primer diperoleh dari hasil wawancara dengan petani, sedangkan data sekunder dari beberapa instansi terkait. Pengukuran ketidakpastian dilakukan menggunakan metode skala likerts. Analisis data di lakukan secara deskriptif kualitatif. Hasil penelitian menemukan adanya keragaman jenis ketidakpastian yang selalu dihadapi petani dalam pemanfaatan lahan pertanian dan ketidakpastian tersebut telah dijadikan dasar oleh petani untuk mempertimbangan jenis komoditi yang akan diusahakan.
\end{abstract}

Kata Kunci: pemanfaatan lahan, ketidakpastian, jenis komoditi, musim tanam

\begin{abstract}
Farmers in utilizing agricultural land always faced with uncertainty. On the other hand, farmers should also consider various types of commodities which will be endeavored that no crop failure. Based on the above, the research is conducted with the objectives: (1) to identify the kinds of uncertainties often faced by farmers in utilizing agricultural land for farming activities; (2) to analyzes the influence of uncertainty on the consideration of farmers in determining the type of commodity to be cultivated. The data collected consist of primary data and secondary data. Primary data was obtained from interview with farmer while secondary data from several related institutions. Measurement of uncertainty is done using likerts scale method. Data analysis is done descriptively qualitative. The results of the study found that the diversity of types of uncertainty often faced by farmers in agricultural land use and the uncertainty has been used as a basis by farmers to consider the types of commodities to be cultivated.
\end{abstract}

Keywords: land use, uncertainty, commodity type, planting season

\section{PENDAHULUAN}

Ketidakpastian petani dalam memanfaatkan lahan pertanian untuk kegiatan usaha tani bukan merupakan hal yang baru. Hal ini terjadi karena pada kenyataannya petani, telah banyak mengambil keputusan terkait dengan ketidakpastian yang penuh resiko. Pada kondisi yang penuh ketidakpastian, petani menentukan keputusan pemanfaatan lahan pertanian sering tidak mengetahui apa yang akan terjadi di masa yang akan datang. Berdasarkan kondisi tersebut maka keputusan yang diambil petani akan mengandung banyak resiko (Soedjana, 2007). Keberanian petani dalan menghadapi resiko ketidakpastian dalam pemanfaatan lahan pertanian membukti bahwa petani mampu melakukan strategi meminimalisir kegagalan atau kerugian usahataninya (Adiyoga dan Soetiarso, 1999)

Ketidakpastian dalam pemanfaatan lahan pertanian dapat dipicu kerana adanya variasi perubahan iklim, fluktuasi harga, modal, bencana alam, kebijakan pemerintah dan kondisi alam lainnya. Petani yang tidak mampu mengambil resiko kegagalan, sering tidak berani dan berspekulasi untuk menentukan perubahan komoditi yang akan diusahakannya sehingga produksi menjadi gagal dan berpengaruh terhadap keputusan petani untuk berusahatani berikutnya (Nelson et al. 1978: Soekartawi, Rusmadi, dan Damaijati, 1993). Ini berarti menurut Saefulhakim dkk. (1994) dan Sudrajat, (2016) ketidakpastian dalam pemanfaatan lahan untuk usahatani merupakan suatu proses yang dinamis, sebagai hasil dari perubahan ketidakpastian dalam waktu dan ruang yang berbeda, sehingga masalah yang berkaitan dengan ketidakpastian pemanfaatan lahan pertanian merupakan masalah yang kompleks yang harus selalu dihadapi oleh petani.

Pembicaraan mengenai pemanfaatan lahan untuk menghindari resiko kerugian dalam kegiatan pertanian pertama kali diperkenalkan oleh Von Thunen (1783) dengan model tataguna lahan pertanian. Model ini 
membicarakan keterkaitan antara letak pemanfaatan lahan pertanian untuk berbagai jenis tanaman dengan jarak dari pusat pemasaran. Di mana jenis tanam yang diusahakan harus mempertimbangkan faktor jarak ke pusat kota sebagai konsekuensi biaya transportani. Penataan ini dilakukan agar petani dalam memanfaatkan lahan pertanian tersebut tidak mengalami resiko kerugian karena adanya ketidakpastian dari sisi aspek ekonomi. Ini berarti keuntungan maksimal hanya akan tercapai jika petani dalam pemanfaatan lahan mempertimbangkan jenis komoditi berdasarkan jarak ke pusat pemasaran. Oleh karena itu, jenis komoditi yang cepat rusak atau busuk untuk menghidari ketidakpastian harga harus ditanam dekat pusat kota, sedangkan yang jauh dari pusat kota disarankan komoditi yang tahan lama.

Ketidakpastian dalam pemanfaatan lahan pertanian telah menyebabkan banyak petani mengalami kerugian akibat ketidakmampuannya dalam beradaptasi dengan kondisi tersebut. Hal ini sejalan dengan yang dikemukan Adiyoga dan Soetiarso, (1999) bahwa petani yang tidak memiliki kemampuan melakukan strategi sebagai adapatasi dalam menghadapi ketidakpastian alam (perubahan iklim dan serangkan hama penyakit tanaman) tidak mendapatkan keuntungan maksimum, sedangkan petani yang mampu melakukan strategi dengan melakukan perubahan pola tanam mendapatkan keuntungan lebih baik. Namun demikian, menurut Soekartawi dkk. (1993) ketidakmampuan petani dalam melakukan adaptasi sangat bergantung pada sikap dan perilaku petani yang dipengaruhi oleh keadaan lingkungan, aspek sosial ekonomi petani seperti umur, pendidikan dan pengalaman usahatani serta faktor sosial lainnya.

Kondisi ketidakpastian yang sering dihadapi petani dan telah menyebabkan resiko kegagalan dalam pemanfaatan usahatani juga sering dialami petani yang ada di Desa Sukasari Kaler. Hal ini terjadi karena kegiatan usahatani di Desa tersebut tidak terlepas juga dari adanya ketidakpastian kondisi fisik alam dan kondisi sosial-ekonomi masyarakatnya. Berdasarkan hal tersebut maka penelitian ini bertujuan untuk mengindentifikasi jenis ketidakpastian yang sering dihadapi petani dalam memanfaatkan lahan pertanian; dan menganalisis pengaruh ketidakpastian terhadap pertimbangan petani dalam menentukan jenis komoditi yang akan diusahakan di Desa Sukasari Keler Kecamatan Argapura.

Hasil penelitian ini paling tidak memiliki dua manfaat yaitu; manfaat secara teroritk atau konseptual dan manfaat secara praktis atau aplikatif. Secara konseptual penelitian ini diharapkan sebagai salah satu bahan kajian ketidakpastian pemanfaatan lahan pertanian dan faktor yang menjadi pertimbangan petani berspekulasi untuk memutuskan jenis komoditi yang akan diusahakannya. Sementara itu, secara aplikatif penelitian ini diharapkan dapat digunakan sebagai dasar pengambilan kebijakan untuk meminimalisasi resiko dari ketidakpastian usahatani. Di sisi lain, hasil penelitian ini juga diharapkan dapat dimanfaatkan oleh para stakeholders atau pihak yang terkait dengan permasalahan ketidakpastian kegiatan pertanian yang dihadapi petani sebagai justifikasi akademis untuk memberikan dukungan dalam berbagai kegiatan seperti, penelitian, pengkajian, pengembangan, pelatihan, penyuluhan dan kegiatan pemberdayaan petani.

Ketidakpastian adalah sesuatu yang tidak bisa diramalkan sebelumnya, dan karenanya peluang terjadinya merugi belum diketahui sebelumnya. Sumber ketidakpastian yang penting di sektor pertanian adalah fluktuasi hasil pertanian yang disebabkan karena faktor alam dan social-ekonomi. Ketidakpastian hasil pertanian yang disebabkan oleh faktor alam diantaranya dalah faktor iklim, hama dan penyakit serta kekeringan. Sementara itu, ketidakpastain dari faktor social ekonomi diantaranya adalah flutuasi harga komoditi pertanian. Akibat terbatasnya penguasaan petani terhadap iklim, pasar tempat menjual komoditi pertanian dan lingkungan institusi tempat berusahatani, maka petani senantiasa dihadapkan pada masalah ketidakpastian terhadap besarnya pendapatan usahatani yang diperoleh. Apalagi bagi petani subsistem yang memiliki keterbatasan sumberdaya maka faktor ketidakpastian merupakan suatu hal yang sangat berpengaruh dalam usahataninya (Soekartawi dkk., 1986). Pada akhirnya kondisi ketidakpastian tersebut akan mempengaruhi pada keputusan petani dalam mengalokasikan inputinput untuk memanfaatkan lahan pertanian dengan komoditi tertentu (Kumbhakar, 2002).

Secara keruangan variasi ketidakpastian dalam memanfaatkan lahan pertanian untuk usahatani dan perkembangan pertanian di muka bumi ini sangat dipengaruhi oleh aspek fisik, sosial, ekonomi, budaya dan politik (Rostam dan Anuar, 1984). Hal senada dikemukan Peter (1968) bahwa kegiatan pertanian yang penuh dengan resiko pada suatu wilayah dipengaruhi oleh empat faktor utama yaitu: (1) faktor alam sekitarnya atau faktor ekologi yang terdapat di suatu wilayah seperti iklim, geomorfologi, asal tanaman dan lahan yang menentukan batas ekologi terhadap suatu jenis tanaman atau ternak; (2) faktor tradisional yang terdiri dari faktor sejarah, perubahan-perubahan dalam masyarakat, organisasi sosial, adat istiadat, agama dan kepercayaan; (3) faktor ekonomi yang terkait dengan keuntungan dalam kegiatan produksi yaitu tenaga kerja, teknologi dan pasar; dan (4) faktor politik yang meliputi kebijakan dan keputusan dari pemerintah terhadap kegiatan pertanian. Kebijakan tersebut dapat berupa kemudahan terhadap kredit, irigasi, transportasi, pemasaran dalam bentuk ekpor dan impor produk pertanian. Faktor faktor tersebut telah menyebabkan adanya variasi pemanfaatan lahan oleh petani dan kenapakan aktivitas pertanian yang menjadi ciri dari wilayah tersebut. 
Menurut Morgan dan Muton (1971) dan Ruthenberg (1980) perbedaan kenampakan hasil interaksi antara manusia dalam memanfaatkan ruang untuk petanian terjadi karena adanya bervariasi ketidakpastian yang dihadapi petani dalam ruang dan waktu. Ini berarti, petani dalam memanfaatkan lahan untuk kegiatan usahatani pada suatu ruang dan waktu tertentu sangat dipengaruhi oleh kondisi ketidakpastian yang terkait dengan aspek fisik maupun non fisik seperti; (1) aspek alam terdiri dari relief, batuan, kesuburan tanah, air, iklim dan sinar matahari; (2) aspek biologis terdiri dari varitas, tanaman pengganggu, hama dan penyakit; dan (3) aspek sosial-ekonomi dan budaya terdiri dari modal, jarak ke pasar, sewa lahan, tenaga kerja, kredit, teknologi, pestisida, kebijakan pemerintah, pengetahuan petani. Hal serupa dikemukan Symons (1966) bahwa manusia dalam memanfaatkan lahan untuk usahatani sangat dipengaruhi ketidapastian yang muncul dari tiga aspek yaitu: (a) faktor fisik terutama yang berkaitan dengan iklim, jenis tanah dan tofografi; (b) faktor sosial seperti ukuran luas lahan, status pemilikan lahan, adat istiadat dan kepercayaan; dan (c) faktor ekonomi seperti pemasaran, transportasi, buruh dan teknologi. Demikian juga, menurut Bachri dkk. (2017) salah satu unsur fisik yaitu kandungan kimia tanah menjadi penting untuk mengetahui tingkat kesuburan dan daya dukung lahan terhadap aktivitas pertanian di suatu wilayah.

Menurut Suparmoko (1995) aktivitas manusia dalam pemanfaatan lahan pertanian untuk usahatani sangat dipengaruhi oleh kelas kemampuan lahan yang dicirikan oleh adanya perbedaan pada sifat-sifat fisik yang menjadi ketidakpastian atau penghambat bagi pemanfaatannya seperti; tekstur tanah, lereng permukaan tanah, kemampuan menahan air dan tingkat erosi yang telah terjadi. Hal yang sama juga dikemukan Barlowe (1986) bahwa ketidakpastian kondisi fisik, biologis, faktor pertimbangan ekonomi dan faktor institusi (kelembagaan) sangat mempengaruhi dalam pemanfaatan lahan untuk usahatani. Faktor fisik dan biologis mencakup kesesuaian dari sifat fisik seperti; keadaan geologi, tanah, air, iklim, tumbuh-tumbuhan, hewan dan kependudukan. Faktor pertimbangan ekonomi dicirikan oleh keuntungan, keadaan pasar dan transportasi. Faktor institusi dicirikan oleh hukum pertanahan, keadaan politik, keadaan sosial dan secara administrasi dapat dilaksanakan.

Menurut Mubyarto (1986) bahwa ketidakpastian petani dalam pemanfaatan lahan untuk kegiatan usahatani sangat dipengaruhi faktor produksi, seperti lahan, modal, tenaga kerja dan keterampilan manajemen dikuasai oleh petani. Lain halnya dengan yang dikemukan Soemihardjo (1991) bahwa ketidapastian petani dalam menentukan keputusannya dalam memanfaatkan lahan pertanian dengan jenis komoditi tertentu adalah status penguasaan lahan. Petani yang menguasai lahan dari hasil menyewa cenderung mengusahakan jenis komoditi komersial yang lebih cepat menghasilkan, seperti tomat, kedelai, tembakau dan sayuran, sedangkan petani penyakap untuk meningkatkan pendapatan dari pertaniannya lebih cenderung mengusahakan tumpangsari dengan sejumlah komoditi. Sementara itu, petani pemilik lebih banyak mengusahakan komoditi padi, jagung, ubi kayu dan kacang tanah. Faktor lain yang juga mempengaruhi keputusan petani dalam pemanfaatan lahan untuk suatu jenis komoditi tertentu adalah biaya produksi, tingkat resiko pada masa pra-panen dan pasca-panen dan pemasaran output.

Menurut Gitoasmoro (1999) variasi perilaku petani dalam menghadapi ketidakpastian dalam pemanfaatan lahan sangat dipengaruhi oleh berbagai aspek yaitu; jarak antara lahan garapan dengan tempat tinggal, pendidikan, frekuensi mengikuti penyuluhan, pemakaian alat pertanian, transportasi, umur petani serta faktor alam yaitu; tekstur tanah, $\mathrm{pH}$, keragaman bahan organik dan bahaya banjir. Hal senada dikemukan Juarini (2003) bahwa perilaku petani terhadap risiko ketidapastian usahatani pada suatu lahan dipengaruhi oleh pengalaman petani dalam berusahatani, jumlah anggota keluarga, bulan tanam, jarak lahan dari irigasi, pola kombinasi irigasi dan jenis tanamannya. Demikian juga, menurut Watters dan Bayer (2003) bahwa proses dan perilaku pengambilan keputusan petani terhadap resiko ketidapastian dalam kegiatan usahatani dipengaruhi oleh budaya masyarakat di mana keluarga tani itu berada, sedangkan variasi sistem pertanian yang ada disuatu wilayah dipengaruhi aspek sosial, ekonomi dan politik.

Sementara itu, menurut Morgan dan Muton (1971) proses kegiatan petani yang penuh dengan ketidakpastian dalam memanfaatkan lahan pertanian sangat dipengaruhi oleh dua keputusan yaitu; (1) berkaitan dengan keputusan tentang perencanaan dan kebijakan, terutama tentang jenis usaha yang akan dilakukan dan penentuan sumberdaya; dan (2) hal yang berkaitan dengan keputusan-keputusan organisasi yang harus dilaksanakan setiap hari, minggu, bulan dan musim yang didasarkan pada keadaan cuaca dan pasar. Keputusan yang dibuat petani tersebut dipengaruhi oleh tiga faktor yaitu; (1) faktor ekonomi yaitu berkaitan dengan pengeluaran, pendapatan dan kekayaan; (2) faktor sosial yaitu berkaitan dengan status sosial, penghargaan, penghormatan ataupun kekuasaan dalam suatu kumpulan atau masyarakat di mana petani tinggal; dan (3) faktor idiologi yaitu berkaitan dengan semangat kebangsaan, tanggungjawab terhadap keluarga dan masyarakat setempat.

\section{METODE PENELITIAN}

Penelitian ini dilakukan di Desa Sukasari Kaler Kecamatan Argapura Kabupaten Majalengka dengan mengambil 60 petani sebagai sampel. Pengambilan 
sampel di lapangan menggunakan metode random sampling. Data yang dikumpulkan terdiri dari dua jenis daa yaitu data primer dan data sekunder. Data primer secara langsung dikumpulkan di lapangan melalui observasi dan wawancara dengan petani menggunakan kuesioner, sedangkan untuk mendapatkan data sekunder dilakukan studi kelembagaan ke beberap instansi terkait. Variabel yang dianalisis dalam penelitian ini meliputi variabel karakteristik sosio-demografi dan ekonomi petani; variabel ketidakpastian yang terkait dengan aspek fisik maupun sosial-ekonomi; dan variabel yang terkait dengan pertimbangan petani dalam menentukan kegiatan usahatani, seperti faktor lingkungan fisik maupun social-ekonomi.

Pengukuran ketidakpastian dalam usahatani petani menggunakan metode skala likert dengan penskoran. Ketidakpastain dilihat dari variabel yang bersifat alamiah dan yang bersifat sosial ekonomi. Ketidakpastian yang bersifat alamiah dalam penelitian ini terkait dengan penurunan kesuburan lahan, perubahan curah hujan (bulan basah dominan), kekeringan/kekurangan air untuk kegiatan pertanian, kemungkinan terjadinya tanah longsor, erosi, hama dan penyakit tanaman, dan jenis variatas, sedangkan. ketidakpastian yang bersifat sosial ekonomi terkait dengan kasus pencurian alat pertanian/hasil produksi, flutuasi harga komoditi, pupuk dan obat-obatan, ketersediaan modal yang dimiliki petani, pembiayaan yang dinvestasikan dalam pertanian, lokasi tempat pemasaran hasil produksi pertanian, besaran kredit/ pinjaman untuk usahatani dan perubahan teknologi yang digunakan dalam pertanian.
Untuk melihat arah kesecenderungan ketidakpastian yang dihadapi petani dilakukan penilai skor dengan cara menjumlah nilai skor yang diperoleh dari survei dari semua item pernyataan. Nilai skor hasil pengukuran dibandingkan dengan nilai skor kuartil Q1, Q2 dan Q3 yang berada di antara batas bawah (A) yaitu; sekor terendah dan batas atas skor tertinggi dari semua item pernyataan. Hasil perhitungan ini menggambarkan tingkat ketidakpastian yang dihadapi petani dalam memanfaatkan lahan pertanian. Jika nilai skor yang diperoleh dari semua petani mengarah ke arah batas bawah melewati kuartil (Q1) maka ketidakpastian yang sering dialami petani mengarah ke arah rendah, sebaliknya jika mengarah ke arah batas bawah melewati kuartil (Q3) maka ketidakpastain yang dialami petani tinggi. Sementara itu, untuk melihat pengaruh ketidakpastian terhadap pertimbangan petani dalam menentukan komoditi yang diusakakan dianalisis secara deskriptif dari hasil wawancara.

\section{HASIL PENELITIAN DAN PEMBAHASAN}

Desa Sukasari Kaler Kecamatan Argapura Kabupaten Majalengka secara administrasi Desa di sebalah utara berbatasan langsung dengan Desa Sadasari, di sebelah selatan berbatasan dengan Desa Sukasari Kidul, di sebelah timur dengan Desa Tejamulya dan di sebelah barat berbatasan dengan Desa Tegalsari (Gambar 1). Luas wilayah Desa Sukasari Kaler sekitar $246,544 \mathrm{ha} / \mathrm{m}^{2}$ dengan ketinggian tempad rata-rata wilayah $700 \mathrm{~m} \mathrm{dpl}$, sedangkan curah hujan rata-rata $300 \mathrm{~mm} /$ bulan. Sementara itu, suhu rata-rata hariannya mecapai $27^{\circ} \mathrm{C}$ (Profil Desa Sukasari Kaler, 2015).

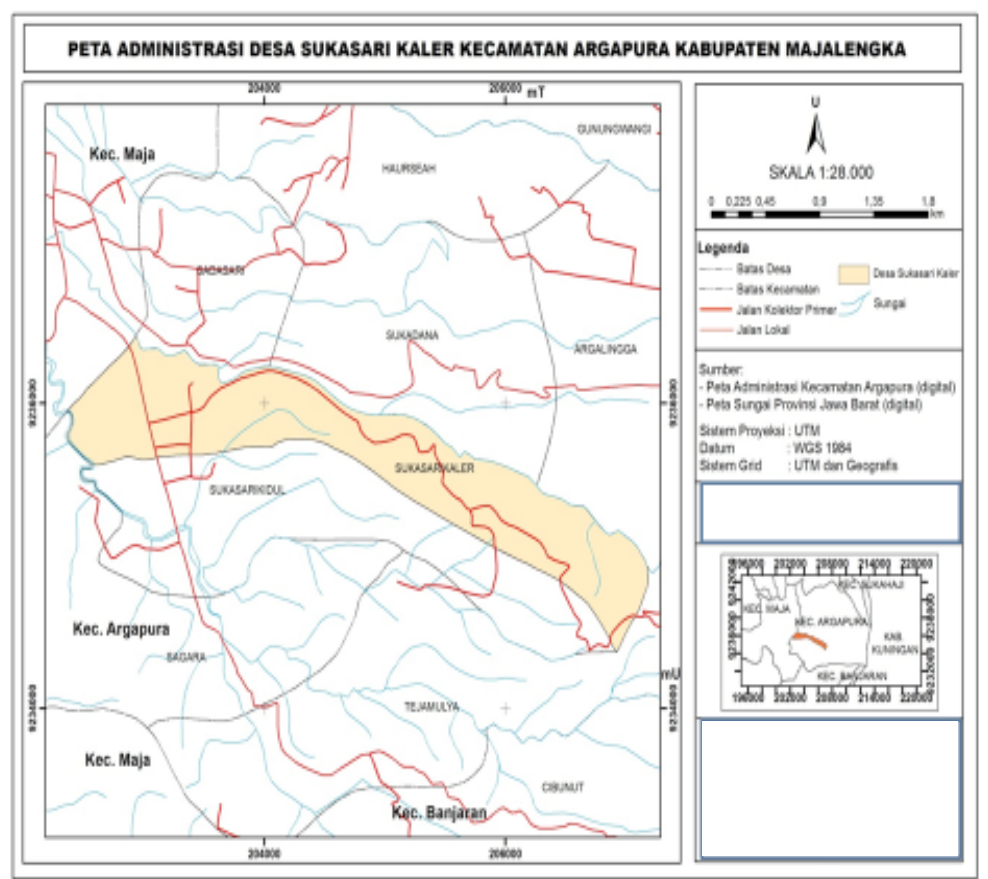

Gambar 1 Peta Administrasi Desa Sukasari Kaler Kecamatan Argapura 
Jumlah penduduk Desa Sukasari Kaler tahun 2015 sebanyak 3.639 jiwa yang terdiri dari penduduk laki-laki sebanyak 1815jiwa dan penduduk perempuan sebanyak 1824 jiwa, sedangkan jumlah kepala keluargnya ada sebanyak 1600 kepala keluarga, diantaranya sebanyak 766 adalah keluarga tani. Sementara itu, dilihat dari mata pencahariannya sebagian besar penduduk Desa Sukasari Kaler adalah petani yaitu sebanyak 2046 jiwa, kemudian buruh tani sebanyak 103 orang, PNS/ TNI/POLRI sebanyak 62 orang, pensiunan PNS/TNI/ POLRI sebanyak 22 dan sebanyak 386 orang penduduk lainnya kurang lebih berprofesi sebagai wiraswasta dan pedagang (Profil Desa Sukasari Kaler, 2015).

\section{Karateristik Keluarga Petani}

Secara umum kondisi sosial-demografi keluarga tani di Desa Sukasari Kaler Kecamatan Argapura cukup keragaman. Salah satu apsek demografi yang cukup menarik untuk dianalisis diantaranya adalah faktor umur. Hal ini terjadi karena umur sering berkaitan dengan produktivitas petani dalam melakukan kegiatan pertanian. Hasil penelitian sebagaimana tercantum pada Tabel 1 menunjukkan sebagian besar umur kepala keluarga tani masih tergolong berumur produktif yaitu umur $<40$ tahun sebanyak $23 \%$, antara $40-65$ tahun $73 \%$ dan $>65$ tahun sebanyak $4 \%$ dengan rata-rata umur 49,1 tahun. Walaupun sebagian besar petani masih tergolong umur produktif, namun perlu diwaspadai samakin meningkatnya jumlah umur tidak produktif karena ada kecenderung meningkatnya penduduk umur produktif mangalir ke kota dan yang sudah tidak produktif lagi kembali mengalir ke desa untuk bekerja di pertanian atau bekerja secara serabutan.

Tabel 1 Distribusi Umur Petani Di Desa Sukasari Kaler Kecamatan Argapura Malajengka

\begin{tabular}{cll}
\hline Kelompok Umur & Frekuensi & Persentase $(\%)$ \\
\hline$<40$ tahun & 14 & 23,3 \\
$40-65$ tahun & 44 & 73,3 \\
$>65$ tahun & 2 & 3,4 \\
Jumlah & 60 & 100
\end{tabular}

Rata-Rata (tahun) 49,1 tahun

Sumber: Data Primer, 2017

Aspek demografi lainnya, yang cukup menarik untuk dianalisis adalah jumlah anggota keluarga petani. Hal ini terjadi karena jumlah anggota keluarga yang besar menjadi salah modal dasar untuk meningkatkan pendapatan, jika sebagian besar bekerja dan sebalik akan menjadi beban tanggungan jika sebagian besar tidak bekerja. Hasil penelitian sebagaimana tercantum pada Tabel 2 menemukan rata-rata jumlah anggota keluarga petani di daerah penelitian hanya sebanyak 3 orang. Sementara itu, dilihat dari distribusinya tampak sebagian besar $(50,0 \%)$ keluarga petani memiliki jumlah anggota keluarga berkisar antara 3-5 orang, kemudian disusul dengan yang memiliki anggota keluarga $>3$ orang sebanyak $48,0 \%$ dan yang memiliki anggota keluarga $<2$ orang hanya sebanyak $2 \%$.

Tabel 2 Distribusi Anggota Keluarga Petani Di Desa Sukasari Kaler Kecamatan Argapura Malajengka

\begin{tabular}{lll}
$\begin{array}{l}\text { Jumlah Anggota } \\
\text { Keluarga Petani }\end{array}$ & Frekuensi & Persentase (\%) \\
\hline 3 orang & 1 & 1,7 \\
3-5 orang & 30 & 50,0 \\
$>5$ orang & 29 & 48,3 \\
Jumlah & 60 & 100 \\
Rata-rata (orang) & 3 Orang & \\
\hline
\end{tabular}

Sumber: Data Primer, 2017

Sementara itu, untuk karakteristik sosial yang dianalisis dalam penelitian ini salah satunya adalah pendidikan.Haliniterjadikarenapendidikanmerupakan salah satu faktor yang menentukan keberhasilan peningkatan kesejahteraan dan pengembangan kualitas sumberdaya manusia. Hasil penelitian sebagaimana tercantum pada Tabel 3 menemukan pendidikan petani di Desa Sukasari Kaler masih didominasi oleh petani yang berpendidikan SD yaitu; mencapai $75 \%$, kemudian yang berpendidikan SLTP sebanyak 18,3\%, yang berpendidikan SLTA sebanyak 3,3\% dan yang tidak tamat SD hanya sebanyak $3,3 \%$. Fenomen ini memberikan gambaran bahwa petani di daerah penelitian memiliki tingkat pendidikannya masih tergolong rendah.

Tabel 3 Distribusi Pendidikan Petani Di Desa

Sukasari Kaler Kecamatan Argapura Malajengka

\begin{tabular}{lll}
\hline Pendidikan & Frekuensi & Persentase (\%) \\
\hline Tidak Tamat SD & 2 & 3,3 \\
SD & 45 & 75,0 \\
SMP & 11 & 18,3 \\
SMA & 2 & 3,3 \\
Jumlah & 60 & 100 \\
\hline
\end{tabular}

Sumber: Data Primer, 2017

Salah satu aspek yang mencerminkan karekteristik ekonomi keluarga petani diantaranya adalah pendapatan keluarga. Pendapatan keluarga petani dapat dikelompokan menjadi dua kelompok yaitu; pendapatan yang berasal dari kepala keluarga dan pendapatan yang berasal dari anggota keluarga, baik yang berasal dari pertanian maupun dari non pertanian, yang menyumbangkan pendapatannya untuk memenuhi kebutuhan hidup keluarga. Pendapatan yang berasal dari anggota keluarga biasanya berasal dari istri, anak atau anggota keluarga lain yang bekerja dan masih tinggal serumah atau yang tidak tinggal serumah tetapi memberikan pendapatan setiap bulannya. Pendapatan kepala keluarga dapat berasal dari pendapatan 
pokok sebagai petani dan pendapatan sampingan yang dilakukan di sela-sela kegiatan pertanian. Jadi, pendapatan keluarga adalah total pendapatan yang diperoleh dari seluruh anggota keluarga yang melakukan kegiatan ekonomi dan menghasilkan pendapatan baik dari sektor pertanian maupun non pertanian untuk memenuhi kebutuhan hidup anggota keluarga. Secara lebih jelas pendapatan total keluarga tani menurut zona penelitian dapat dilihat pada Tabel 4 .

Tabel 4 Distribusi Pendapatan Keluarga Petani di Desa Sukasari Kaler Kecamatan Argapura Majalengka

\begin{tabular}{lll}
\hline Pendapatan Keluarga & Frekuensi & Persentase (\%) \\
\hline$<$ Rp 5.000.000,- & 34 & 55,6 \\
Rp 5.000.000 - 10.000.000,- & 16 & 26,7 \\
$>$ Rp 10.000.000,- & 10 & 16,7 \\
Total & 60 & 100,0 \\
Rata-rata (Rp/bulan) & $5.707 .208,-$ \\
\hline
\end{tabular}

Sumber: Data Primer 2017

Hasil penelitian sebagaimana tercantum pada Tabel 4 tampak rata-rata pendaparan keluarga petani sebesar Rp 5.707.208,- per bulan. Sementara itu, dilihat dari distribusinya tampak keluarga yang memiliki pendapatan <Rp 5.000.000,- per bulan ditemukan cukup dominan yaitu mencapai sebanyak 55,6\%, yang memiliki pendapatan keluarga antara Rp 5.000.00010.000.000,- per bulan sebanyak $26,7 \%$ dan yang memiliki pendapatan keluarga $>$ Rp 10.000.000,- per bulan han sebanyak $16,7 \%$. Besarnya variasi pendapatan keluarga tani yang diterima setiap bulannya sangat ditentukan oleh besarnya sumbangan pendapatan dari hasil usahatani kepela keluarga dan sumbangan pendapatan yang berasal dari anggota keluarga, baik dari hasil pertanian maupun non-pertanian.

\section{Jenis Ketidakpastian Dalam Memanfaatkan Lahan Pertanian}

Ketiadakpastian dalam usahatani diartikan sebagai suatu situasi pada suatu keadaan atau kejadian di masa mendatang yang tidak dapat diduga secara pasti oleh petani dalam kegiatan usahataninya. Masalah ketidakpastian bagi petani di bidang pertanian bukan merupakan hal baru karena pada kenyataannya petani telah banyak mengambil keputusan yang berkaitan dengan ketidakpastian. Jenis ketidakpastian dapat dibedakan menjadi dua yaitu ketidakpastian yang bersifat alamiah dan yang bersifat sosio-ekonomi.

\section{Ketidapastian Yang Bersifat Alamiah}

Ketidakpastian usahatani yang bersiaf alamiah adalah suatu situasi pada suatu keadaan atau kejadian yang disebabkan oleh alam di masa mendatang yang tidak dapat diduga secara pasti oleh petani dalam kegiatan usahataninya. Ketidakpastian yang bersifat alamiah diantaranya terkait dengan penurunan kesuburan lahan, perubahan curah hujan (bulan basah dominan), kekeringan/kekurangan air unrtuk kegiatan pertanian, kemungkinan terjadinya tanah longsor, erosi, hama dan penyakit tanaman, dan jenis variatas. Jenis ketidakpastian yang bersifat alamiah menurut persepsi petani dilihat pada Tabel 5 .

Tabel 5. Jenis Ketidakpastian Yang Bersifat Alamiah Menurut Persepsi Petani di Desa Sukasari Kaler Kecamatan Argapura Majalengka

\begin{tabular}{|c|c|c|c|c|c|c|}
\hline $\begin{array}{l}\text { Jenis Ketidakpastian Yang Bersifat } \\
\text { Alamiah }\end{array}$ & STS & TS & $\mathrm{R}$ & $S$ & SS & Jumlah \\
\hline $\begin{array}{l}\text { Penurunan kesuburan lahan } \\
\text { pertanian }\end{array}$ & $\begin{array}{c}0 \\
(0,0)\end{array}$ & $\begin{array}{c}4 \\
(6,7)\end{array}$ & $\begin{array}{c}2 \\
(3,3)\end{array}$ & $\begin{array}{c}48 \\
(80,0)\end{array}$ & $\begin{array}{c}6 \\
(10,0)\end{array}$ & $\begin{array}{c}60 \\
(100,0)\end{array}$ \\
\hline $\begin{array}{l}\text { Perubahan curah hujan (bulan } \\
\text { basah dominan) }\end{array}$ & $\begin{array}{c}0 \\
(0,0)\end{array}$ & $\begin{array}{c}4 \\
(6,7)\end{array}$ & $\begin{array}{c}1 \\
(1,7)\end{array}$ & $\begin{array}{c}25 \\
(41,6)\end{array}$ & $\begin{array}{c}30 \\
(50,0)\end{array}$ & $\begin{array}{c}60 \\
(100,0)\end{array}$ \\
\hline $\begin{array}{l}\text { Kekeringan/kekuranga air pada } \\
\text { musim kemarau }\end{array}$ & $\begin{array}{c}5 \\
(8,3)\end{array}$ & $\begin{array}{c}27 \\
(45,0)\end{array}$ & $\begin{array}{c}0 \\
(0,0)\end{array}$ & $\begin{array}{c}26 \\
(43,3)\end{array}$ & $\begin{array}{c}2 \\
(3,3)\end{array}$ & $\begin{array}{c}60 \\
(100,0)\end{array}$ \\
\hline $\begin{array}{l}\text { Kemungkinan terjadinya longsor } \\
\text { pada lahan pertanian }\end{array}$ & $\begin{array}{c}10 \\
(16,7)\end{array}$ & $\begin{array}{c}47 \\
(78,3)\end{array}$ & $\begin{array}{c}2 \\
(3,3)\end{array}$ & $\begin{array}{c}1 \\
(1,7)\end{array}$ & $\begin{array}{c}0 \\
(0,0)\end{array}$ & $\begin{array}{c}60 \\
(100,0)\end{array}$ \\
\hline $\begin{array}{l}\text { Kemungkinan terjadinya erosi } \\
\text { tanah/lahan pertanian }\end{array}$ & $\begin{array}{c}4 \\
(6,7)\end{array}$ & $\begin{array}{c}54 \\
(90,0)\end{array}$ & $\begin{array}{c}1 \\
(1,7)\end{array}$ & $\begin{array}{c}1 \\
(1,7)\end{array}$ & $\begin{array}{c}0 \\
(0,0)\end{array}$ & $\begin{array}{c}60 \\
(100,0)\end{array}$ \\
\hline $\begin{array}{l}\text { Hama dan penyakit tanaman yang } \\
\text { menyerang tanaman pertanian }\end{array}$ & $\begin{array}{c}0 \\
(0,0)\end{array}$ & $\begin{array}{c}3 \\
(5,0)\end{array}$ & $\begin{array}{c}8 \\
(13,3)\end{array}$ & $\begin{array}{c}35 \\
(58,3)\end{array}$ & $\begin{array}{c}14 \\
(23,3)\end{array}$ & $\begin{array}{c}60 \\
(100,0)\end{array}$ \\
\hline $\begin{array}{l}\text { Jenis variates tanaman yang } \\
\text { diusahakan }\end{array}$ & $\begin{array}{c}4 \\
(6,7)\end{array}$ & $\begin{array}{c}41 \\
(68,3)\end{array}$ & $\begin{array}{c}4 \\
(6,7)\end{array}$ & $\begin{array}{c}5 \\
(8,3)\end{array}$ & $\begin{array}{c}6 \\
(10,0)\end{array}$ & $\begin{array}{c}60 \\
(100,0)\end{array}$ \\
\hline
\end{tabular}

Sumber: Data Primer, 2017

\section{Keterangan:}

STS=Sangat Tidak Setuju, TS= Tidak Setuju, R=Ragu-Ragu, S=Sutuju, SS=Sangat Setuju. 
Hasil penelitian sebagaimana tercantum pada Tabel 5 menunjukkan adanya variasi persepsi petani terhadap ketidakpastian yang bersifat alamiah. Hal ini tampak pada persepsi petani terkait dengan penurunan kesuburan lahan pertanian sebagian besar petani mengatakan setuju sebanyak $80,0 \%$, sangat setuju $10 \%$, sedangkan yang tidak setuju $6,7 \%$ dan yang ragu-ragu hanya $3,3 \%$. Ini berarti bahwa perubahan penurunan kesuburan lahan secara alami oleh petani dianggap sesuatu hal yang sering terjadi pada lahan pertaniannya. Kondisi ini tentu akan memberikan resiko yang bisa merugikan petani karena untuk memulihkannya petani harus kembali melakukan menyuburkan lahan pertanian dengan melakukan pemupukan.

Pada persepsi petani terkait dengan perubahan curah hujan (bulan basah dominan) tampak petani yang mengatakan sangat setuju lebih dominan yaitu sebanyak $50,0 \%$ dan setuju sebanyak $41,6 \%$, sedangkan yang tidak setuju hanya sebanyak 6,7\% dan yang ragu-ragu hanya sebanyak 1,7\%. Fenomena ini memberikan gambaran juga bahwa di lokasi penelitian ketidakpastian yang terkait dengan perubahan curah hujan (bulan basah dominan) oleh petani telah dianggap sebagai bagian yang dapat menghambat kegiatan pertanian yang tidak bisa diprediksi. Hal ini terjadi karena perubahan iklim yang dicirikan dengan tingginya curah hujan (bulan basah lebih lama) sering merugikan petani yang sedang maupun yang akan menanam tanaman bawang merah maupun tanaman holtikultura lainnya.

Pada persepsi petani terkait dengan kekeringan atau kekuranga air untuk kegiatan pertanian tampak petani yang mengatakan tidak setuju lebih dominan yaitu mencapai $45,0 \%$ dan yang sangat tidak setuju $8,3 \%$, sedangkan yang setuju sebanyak $43,3 \%$ dan setuju sebanyak 3,3\%. Ini berarti petani di lokasi penelitian punya padangan yang berbeda terhadap kondisi kekeringan atau kekurang air untuk pertanianya. Hal ini terjadi karena adanya perbedaan topografi lahan yang berbukit dan bergelombang serta perbedaan terhadap lokasi sumber airnya. Pada petani yang memiliki lahan dekat sumber air dan lahanya sedikit bergelombang memiliki sumber airnya lebih mudah diperoleh, sedangkan pada daerah yang berbukit dan jauh dari sumber airnya sering merasakan kekurangan air disaat musim kemarau pajang.

Pada persepsi petani terkait dengan kemungkinan terjadinya longsor pada lahan pertanian tampak sebagian besar petani mengatakan tidak setuju yaitu sebanyak $78,3 \%$, dan sangat tidak setuju sebanyak 16,3 sedangkan yang mengatakan setuju hanya 1,7 dan raguragu sebanyak 3,3\%. Hal yang sama pada persepsi petani terkait dengan kemungkinan terjadinya erosi pada tanah/lahan pertaniannya, tampak sebagian besar petani mengatakan tidak setuju yaitu sebanyak 90,0\%, kemudian yang menyatakan sangat tidak setuju sebanyak 6,7\%, sedangkan yang mengatakan setuju hanya $1,7 \%$ dan raguragu sebanyak $1,7 \%$. Kondisi ini memberikan gambaran bahwa di lokasi penelitian kejadian longsor maupun erosi tanah pada lahan pertanian tidak banyak terjadi atau tidak banyak dirasakan petani. Besarnya jumlah petani yang mengatakan tidak setuju dan sangat tidak setuju terkait dengan kemungkinan terjadinya erosi maupun tanah longsor pada lahan pertaniannya, kemungkinan petani tidak terlalu pahan dengan yang dimaksud erosi maupun longsor lahan. Padahal lokasi lahan pertanianya berbukit dan bergelombang dengan intensitas pemanfaatan lahan sangat intensif sehingga berpeluang terjadinya erosi maupun longsor lahan sangat besar.

Pada persepsi petani terkait dengan hama dan penyakita tanaman yang dapat menyerang tanaman pertanian, tampak petani yang mengatakan sangat setuju lebih dominan yaitu; sebanyak 58,0\% dan setuju sebanyak $23,3 \%$, sedangkan yang tidak setuju hanya sebanyak 5,0\% dan ragu-ragu hanya sebanyak $13,3 \%$. Fenomena ini memberikan gambaran bahwa di lokasi penelitian ketidakpastian yang terkait dengan hama dan penyakita tanaman yang dapat menyerang tanaman pertanian, oleh petani telah dianggap sebagai bagian yang dapat menghambat kegiatan pertanian. Hal ini terjadi karena hama dan penyakit tanaman sering datang secara tiba-tiba, sehingga petani harus mengeluarkan biaya ekstra untuk menanggulanginya.

Pada persepsi petani terkait dengan jenis variatas tanaman yang diusahakan tampak sebagian besar petani mengatakan tidak setuju yaitu; sebanyak $68,3 \%$, kemudian yang menyatakan sangat tidak setuju sebanyak $6,7 \%$, sedangkan yang mengatakan setuju $8,3 \%$, kemudian yang sangat setuju sebanyak $10,0 \%$ dan yang ragu-ragu hanya sebanyak $6,7 \%$. Fenomena ini memberikan juga gambaran bahwa di lokasi penelitian ketidakpastian yang terkait dengan jenis variatas tanaman yang diusahakan, oleh petani tidak dianggap sebagai bagian yang dapat menghambat kegiatan pertanian. Hal ini terjadi karena jika salah memilih variatas unggul sering sekali tanamannya tumbuh menjadi tidak baik dan akan mudah terserang penyakit dan hama tanaman sehingga produktivitas menjadi rendah.

\section{Ketidakpastian Yang bersifat Sosial-Ekonomi}

Ketidakpastian yang bersifat sosial-ekonomi adalah sebagai suatu situasi pada suatu keadaan atau kejadian yang disebabkan oleh aspek sosio-ekonomi yang bisa terjadi di masa mendatang yang tidak dapat diduga secara pasti. Ketidakpastian yang bersifat sosialekonomi dalam penelitian ini terkait dengan kasus pencurian alat pertanian/hasil produksi, fluktuasi harga jual hasil komoditi, ketersediaan modal yang dimiliki petani, fluktuasi harga pupuk dan obat-obatan, lokasi tempat pemasaran hasil produksi pertanian, besaran kredit/pinjaman untuk usahatani dan perubahan teknologi yang digunakan dalam pertanian. Secara lebih jelas persepsi petani terhadap ketidakpastian aspek sosial-ekonomi dapat dilihat pada Tabel 6. 
Tabel 6 Jenis Ketidakpastian Yang Bersifat Sosial-Ekonomi Menurut Petani di Desa Sukasari Kaler Kecamatan Argapura Majalengka

\begin{tabular}{|c|c|c|c|c|c|c|}
\hline $\begin{array}{l}\text { Jenis Ketidakpastian Yang } \\
\text { Bersifat Sosial-Ekonomi }\end{array}$ & STS & TS & $\mathrm{R}$ & $S$ & SS & Jumlah \\
\hline $\begin{array}{l}\text { Kasus pencurian alat } \\
\text { pertanian/hasil produksi }\end{array}$ & $\begin{array}{c}6 \\
(10,0)\end{array}$ & $\begin{array}{c}47 \\
(78,4)\end{array}$ & $\begin{array}{c}0 \\
(0,0)\end{array}$ & $\begin{array}{c}5 \\
(8,3)\end{array}$ & $\begin{array}{c}2 \\
(3,3)\end{array}$ & $\begin{array}{c}60 \\
(100,0)\end{array}$ \\
\hline $\begin{array}{l}\text { Flutuasi harga penjualan } \\
\text { hasil produk pertanian }\end{array}$ & $\begin{array}{c}1 \\
(1,7)\end{array}$ & $\begin{array}{c}16 \\
(26,7)\end{array}$ & $\begin{array}{c}0 \\
(0,0)\end{array}$ & $\begin{array}{c}39 \\
(65,0)\end{array}$ & $\begin{array}{c}4 \\
(6,7)\end{array}$ & $\begin{array}{c}60 \\
(100,0)\end{array}$ \\
\hline $\begin{array}{l}\text { Ketersediaan modal untuk } \\
\text { pembiayaan usahatani yang } \\
\text { dimiliki petani }\end{array}$ & $\begin{array}{c}0 \\
(0,0)\end{array}$ & $\begin{array}{c}7 \\
(11,7)\end{array}$ & $\begin{array}{c}12 \\
(20,0)\end{array}$ & $\begin{array}{c}33 \\
(55,0)\end{array}$ & $\begin{array}{c}8 \\
(13,3)\end{array}$ & $\begin{array}{c}60 \\
(100,0)\end{array}$ \\
\hline $\begin{array}{l}\text { Fluktuasi harga pupuk dan } \\
\text { obat-obatan }\end{array}$ & $\begin{array}{c}0 \\
(0,0)\end{array}$ & $\begin{array}{c}29 \\
(48,3)\end{array}$ & $\begin{array}{c}10 \\
(16,7)\end{array}$ & $\begin{array}{c}15 \\
(25,0)\end{array}$ & $\begin{array}{c}6 \\
(10,0)\end{array}$ & $\begin{array}{c}60 \\
(100,0)\end{array}$ \\
\hline $\begin{array}{l}\text { Kesulitan } \\
\text { pemasaran } \\
\text { pertanian }\end{array}$ & $\begin{array}{c}11 \\
(18,3)\end{array}$ & $\begin{array}{c}46 \\
(61,7)\end{array}$ & $\begin{array}{c}0 \\
(0,0)\end{array}$ & $\begin{array}{c}2 \\
(3,3)\end{array}$ & $\begin{array}{c}1 \\
(1,7)\end{array}$ & $\begin{array}{c}60 \\
(100,0)\end{array}$ \\
\hline $\begin{array}{l}\text { Besaran kredit/pinjaman } \\
\text { untuk usahatani }\end{array}$ & $\begin{array}{c}3 \\
(5,0)\end{array}$ & $\begin{array}{c}26 \\
(43,4)\end{array}$ & $\begin{array}{c}8 \\
(13,3)\end{array}$ & $\begin{array}{c}21 \\
(35,0)\end{array}$ & $\begin{array}{c}2 \\
(3,3)\end{array}$ & $\begin{array}{c}60 \\
(100,0)\end{array}$ \\
\hline $\begin{array}{l}\text { Perubahan teknologi yang } \\
\text { digunakan dalam pertanian }\end{array}$ & $\begin{array}{c}5 \\
(8,3)\end{array}$ & $\begin{array}{c}50 \\
(83,8)\end{array}$ & $\begin{array}{c}5 \\
(8,3)\end{array}$ & $\begin{array}{c}0 \\
(0,0)\end{array}$ & $\begin{array}{c}0 \\
(0,0)\end{array}$ & $\begin{array}{c}60 \\
(60,0)\end{array}$ \\
\hline
\end{tabular}

Sumber: Data Primer, 2017

\section{Keterangan:}

STS=Sangat Tidak Setuju, TS= Tidak Setuju, R=Ragu-Ragu, S=Setuju, SS=Sangat Setuju.

Hasil penelitian sebagaimana tercantum pada Tabel 6 menunjukkan persepsi petani terhadap ketiadkapastian yang bersifat sosial-ekonomi juga cukup bervariasi. Hal ini tampak dari persepsi petani terkait dengan kasus pencurian alat pertanian/hasil produksi, tampak sebagian petani mengatakan tidak setuju yaitu sebanyak 78,4\%, kemudian yang mengatakan sangat tidak setuju sebanyak 10,0\%, sedangkan yang mengatakan setuju $8,3 \%$, dan yang ragu-ragu sebanyak $3,3 \%$. Fenomena ini memberikan gambaran bahwa di lokasi penelitian ketidakpastian yang terkait dengan kasus pencurian alat pertanian/hasil produksi pertanian tidak dianggap sebagai bagian yang dapat menghambat kegiatan pertanian. Hal ini terjadi karena di lokasi penelitian kasus pencurian alat pertanian maupun hasil produksi pertanian sangat jarang terjadi.

Pada persepsi petani terkait dengan fluktuasi harga penjualan produk pertanian, tampak petani yang mengatakan setuju lebih dominan yaitu sebanyak $65,0 \%$ dan setuju sebanyak $6,7 \%$, sedangkan yang tidak setuju sebanyak 26,7\%, kemudian yang sangat tidak setuju sebanyak $1,7 \%$ dan yang ragu-ragu hanya sebanyak 13,3\%. Fenomena ini memberikan gambaran bahwa di lokasi penelitian ketidakpastian yang terkait dengan fluktuasi harga penjualan produk pertanian yang dirasakan petani, dianggap oleh sebagian besar petani sebagai penghambat dalam kegiatan pertanian dan hanya sebagian kecil saja yang tidak menganggap sebagai penghambat. Hal ini terjadi karena fluktuasi harga produk pertanian diatur oleh mekanisme pasar.

Pada persepsi petani terkait dengan ketersediaan modal untuk pembiayaan usahatani yang dimiliki petani, tampak petani yang mengatakan setuju lebih dominan yaitu sebanyak 55,0\% dan setuju sebanyak $13,3 \%$, sedangkan yang tidak setuju sebanyak $11,7 \%$ dan yang ragu-ragu hanya sebanyak 20,0\%. Fenomena ini memberikan gambaran bahwa di lokasi penelitian ketidakpastian yang terkait dengan ketersediaan modal untuk pembiayaan yang dimiliki petani, dianggap oleh sebagian besar petani sebagai penghambat dalam kegiatan pertanian dan hanya sebagian kecil saja yang tidak menganggap sebagai penghambat. Hal ini terjadi karena ketersediaan modal untuk pembiayaan usaha yang dimiliki petani sangat ditemtukan oleh kodisi keuangan petani dari hasil usahataninya. 
Pada persepsi petani terkait fluktuasi harga pupuk dan obat-obatan dalam pertanian tampak petani yang mengatakan ke arah setuju dan ke arah tidak setuju hampir seimbang. Fenomena ini memberikan gambaran bahwa di lokasi penelitian ketidakpastian yang terkait dengan fluktuasi harga pupuk dan obatobatan dalam pertanian, dianggap oleh sebagian petani sebagai penghambat dalam kegiatan pertanian dan sebagian lagi tidak menganggap sebagai penghambat. Bagi petani yang memiliki persesi sebagai pengahambat terjadi karena jika harga pupuk dan obat-obatan tidak menentu maka petani akan kesulitan memprediksi biaya usahatani dan sebaliknya bagi yang cukup modal pembiayaan usahatani sering tidak menjadi masalah karena mereka selalu siap dengan dana cadanganya jika terjadi sesuatu yang perlu tambahan biaya.

Pada persepsi petani terkait dengan kesulitan lokasi tempat pemasaran hasil produksi pertanian, tampak sebagian petani mengatakan tidak setuju yaitu sebanyak 76,7\%, kemudian yang menyatakan sangat tidak setuju sebanyak $18,3 \%$, sedangkan yang mengatakan setuju 3,3\%, dan sangat setuju hanya sbanyak $1,7 \%$. Fenomena ini memberikan gambaran bahwa di lokasi penelitian ketidakpastian yang terkait dengan kesulitan lokasi tempat pemasaran hasil produksi pertanian tidak dianggap sebagai bagian yang dapat menghambat kegiatan pertanian. Hal ini terjadi karena di lokasi penelitian tempat pemasaran hasil produksi pertanian dianggap tidak sulit, karena banyak tengkulak atau pengepul yang datang ke lokasi untuk membeli hasil produk pertanian.

Pada persepsi petani terkait dengan besaran kredit/pinjaman untuk usahatani tampak petani yang mengatakan ke arah setuju dan ke arah tidak setuju hampri seimbang juga. Fenomena ini memberikan gambaran bahwa di lokasi penelitian ketidakpastian yang terkait dengan besaran kredit/pinjaman untuk usahatani, dianggap oleh sebagian petani sebagai penghambat dalam kegiatan pertanian dan sebagian lagi tidak dianggap sebagai penghambat. Bagi petani yang memiliki persepsi sebagai penghambat terjadi karena besaran kredit/pinjaman untuk usahatani akan menjadi bakutimbang antara pembayaran kridit dan pembelian input produksi pertanian. Sebaliknya bagi yang tidak memliki pinjaman kredit usahatani tidak menjadi masalah karena dana akan selalu disiapkan untuk pembelian input usahatani sehingga tidak terganggu oleh pengeluaran pembayaran kredit.

Pada persepsi petani terkait dengan perubahan teknologi yang digunakan dalam pertanian tampak sebagian besar petani mengatakan tidak setuju sebanyak $83,8 \%$ dan sangat tidak setuju sebanyak $8,3 \%$, sedankan sisanya sebanyak $8,3 \%$ ragu-ragu. Fenomena ini memberikan gambaran bahwa di lokasi penelitian ketidakpastian yang terkait dengan perubahan teknologi yang digunakan dalam pertanian tidak dianggap sebagai bagian yang dapat menghambat kegiatan pertanian. Hal ini terjadi karena di lokasi teknologi yang digunakan sebagian besar masih sederhana dan tidak banyak mengalami perubahan. Hal ini terjadi karena di lokasi usahataninya memiliki topografi yang berbukit dan bergelombang dengan sistem petanian terasering, sehingga jika menggunakan teknologi modern yang berat tidak cocok untuk diterapkan.

Sementara itu, untuk melihat arah kecenderungan persepsi petani terhadap ketidakpastian dalam pemanfaatan lahan pertanian maka dilakukan pengihitung nilai skornya. Nilai skor yang diberikan responden kemudian dibandingkan dengan nilai total Q1, Q2, Q3, nilai batas bawah (A) dan batas atas (B). Hasil perhitungan dari semua pernyataan yang terkait dengan ketidakpastian dalam dalam pemanfaatan lahan pertanian diperoeh nilai total skor sebanyak 2655. Nilai tersebut berada diantara Q1 dengan nilai skor 1.800 dan Q2 dengan nilai skor 2700 (Gambar 2).

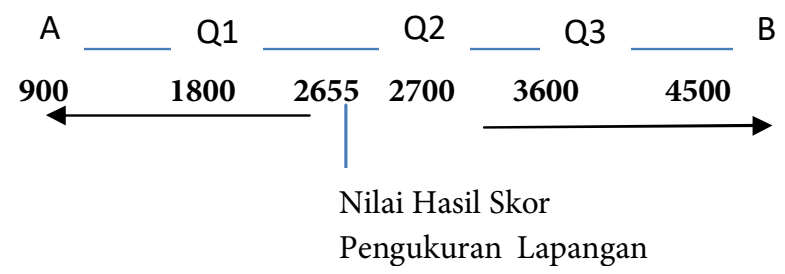

Gambar 2 Nilai Skor Keditdakpastian dalam Pemanfaatan Lahan Pertanain.

\section{Keterangan:}

$\mathrm{A}=$ Skor batas bawah

$\mathrm{B}=$ Skor batas atas

Q1= Skor Kuartil 1

Q2= Skor Kuartil 2

Q3= Skor Kuartil 3

Hasil perhitungan sebagaimana tercantum pada Gambar 2 menunjukkan bahwa arah persepsi petani terhadap ketidakpastian dalam kegiatan pemanfaatan lahan pertanian tergolong rendah. Artinya, ketidakpastian yang selalu mengancam petani dalam melakukan kegiatan pertanian lahan tidak dianggap sebagai hambatan yang luar biasa. Hal ini bisa terjadi karena beberapa petani mampu beradaptasi atau menyesuaikan dengan situasi yang kemungkinan bisa terjadi, baik karena pengaruh faktor aalmiah maupun kerena faktor sosial-ekonomi. Sebagai contoh ada beberap petani yang menyesuaikan diri ketika terjadi musim hujang yang cukup panjang dengan tidak mengusahakan tanaman bawang merah yang biasanya rutin diusahakan, tetapi beralih pada tanaman holtikultura lainnya yang tahan terhadap curah hujan tinggi. Contoh lainnya untuk menghindari terjadi longsor dan erosi pada lahan pertanianya, semua petani yang memiliki lahan pertanian di daerah perbukitan membuat terasering jenis bangku. 
Pengaruh Ketidakpastian Terhadap Pertimbangan Petani Menentukan Jenis Komoditi

Keputusan petani untuk menentukan jenis komoditi tertentu yang akan ditanam pada lahan pertanian sawah maupun tegalan tidak terlepas dari berbagai pertimbang atas dasar ketidakpastaian. Pertimbangan tersebut dilakukan sebagai upaya untuk mendapatkan keuntungan yang sebesar-besarnya dari hasil usahatani yang penuh ketidakpastain. Namun demikian, tidak selamanya pertimbangan petani sebagai keputusannya tepat, tetapi terkadangan juga meleset dari yang diharapkan petani karena adanya pengaruh ketidakpastian.

\section{Pertimbangan Petani Menentukan Jenis Komoditi Pada Lahan Sawah}

Perbedaan kondisi ketidakpastian dalam pemanfatanan lahan sawah menyebabkan adanya variasi jenis komoditi yang diusahakan petani pada setiap musim tanam. Hal ini terjadi karena pilihan jenis komoditi yang akan ditanam tersebut sangat dipengaruhi oleh keputusan petani atas dasar faktor ketidakpastian. Beberapa pertimbangan petani dalam menentukan jenis komoditi yang akan diusakan pada lahan sawah atas dasar pertimbangan ketidakpastian tampak pada Tabel 7.

Tabel 7 Pertimbangan Petani Dalam Menentukan Jenis Komoditi Pada Setiap Musim Tanam (MT) Pada Lahan Sawah

\begin{tabular}{lcc}
\hline $\begin{array}{l}\text { A. Pertimbangan Menanam Jenis Komoditi Pada MT I Pada } \\
\text { Lahan Sawah }\end{array}$ & Frekuensi & Persentase (\%) \\
\hline $\begin{array}{l}\text { 1. Kemudahan menjual hasilnya, Kemudahan mendapatkan } \\
\text { bibit, Kemudahan mendapatkan pupuk dan obat-obatan }\end{array}$ & 2 & 20,0 \\
$\begin{array}{l}\text { 2. Menyesuaikan kondisi cuaca, merasa cocok dengan kondisi } \\
\text { lahan dan air }\end{array}$ & 2 & 20,0 \\
$\begin{array}{l}\text { 3. Kemudahan merawatnya , tahan terhadap hama dan } \\
\text { penyakit }\end{array}$ & 4 & 40,0 \\
$\begin{array}{l}\text { 4. Sudah turun temurun/kebiasaan } \\
\text { 5. Sebagian untuk Konsumsi keluarga }\end{array}$ & 1 & 10,0 \\
Total & 1 & 10,0 \\
\hline
\end{tabular}

B. Pertimbangan Menanam Jenis Komoditi Pada MT II Pada
Lahan Sawah $\quad$ Frekuensi Persentase

1. Kemudahan menjual hasilnya, Kemudahan mendapatkan bibit, Kemudahan mendapatkan pupuk dan obat-obatan

Frekuensi Persentase

2. Harga jual tinggi, hasil produksi tinggi, menyesuaikan kondisi cuaca, merasa cocok dengan kondisi lahan dan air

\begin{tabular}{lc}
1 & 1,7 \\
2 & 20,0 \\
5 & 50,0 \\
2 & 30,0 \\
10 & 100,0 \\
\hline
\end{tabular}

3. Hasil produksi tinggi, menyesuaikan kondisi cuaca, air dan lahan

4. Biaya produksi murah, Kemudahan merawat, tahan terhadap hama dan penyakit

rekuensi Persentase

C. Pertimbangan Menanam Jenis Komoditi Pada MT III Pada Lahan Sawah

Persentase

\begin{tabular}{|c|c|c|}
\hline $\begin{array}{l}\text { 1. Kemudahan menjual hasilnya, Kemudahan mendapatkan } \\
\text { bibit, Kemudahan mendapatkan pupuk dan obat-obatan }\end{array}$ & 3 & 30,0 \\
\hline $\begin{array}{l}\text { 2. Harga jual tinggi, hasil produksi tinggi, menyesuaikan kondisi } \\
\text { cuaca, merasa cocok dengan kondisi lahan dan air }\end{array}$ & 5 & 50,3 \\
\hline $\begin{array}{l}\text { 3. Merasa cocok dengan kondisi lahan dan air, menyesuaikan } \\
\text { kondisi cuaca }\end{array}$ & 2 & 20,3 \\
\hline Total & 10 & 100,0 \\
\hline
\end{tabular}

Sumber: Data Primer, 2017 
Hasil penelitian sebagaimana tercantum pada Tabel 7 tampak dari 10 petani pemilik lahan sawah memiliki pertimbangan yang cukup bervariasi dalam menentukan jenis komoditi yang akan ditanam pada musim tanam ke 1 , ke 2 maupun ke 3 . Pada musim tanam ke 1 yang di dominasi oleh jenis tanaman padi, tampak pertimbangan yang paling dominan adalah kemudahan merawat tanaman, tanaman tahan terhadap hama dan penyakit, kemudian disusul kemudahan menjua hasilnya, mendapatkan bibit, mendapatkan pupuk dan obat-obatan serta menyesuaikan dengan kondisi cuaca, merasa cocok dengan kondisi lahan dan air, sedangkan untuk pertimbangan karena sudah turun temurun/kebiasaan dan untuk pemenuhan kebutuhan konsumsi keluarga relatif sangat sedikit. Pada musim tanam ke 2 yang didominasi jenis tanaman padi, kemudian bawang merah dan bawang daun, tampak pertimbangan yang paling dominan adalah hasil produksi tinggi dan menyesuaikan kondisi cuaca, merasa cocok dengan kondisi lahan dan air, kemudian diikuti dengan harga jual yang tinggi, hasil produksi tinggi dan menyesuaikan kondisi cuaca, merasa cocok dengan kondisi lahan dan air, kemudian biaya produksi murah, kemudahan merawatnya, tahan terhadap hama dan penyakit, serta karena alasan merasa cocok dengan kondisi lahan dan air serta menyesuaikan dengan kondisi cuaca. Sementara itu, pada musim tanam ke 3 yang didominasi tanaman bawang merah dan bawang daun, tampak pertimbangan yang paling dominan adalah harga jual tinggi, hasil produksi tinggi, menyesuaikan kondisi cuaca, kemudian disusul kemudahan menjual hasilnya, mudah mendapatkan bibit, mudah mendapatkan pupuk dan obat-obatan serta pertimbangan karena merasa cocok dengan kondisi lahan dan air, dan menyesuaikan kondisi cuaca. Kodisi ini memberikan gambaran bahwa petani di daerah penelitian sudah bersifat rasional dalam melakukan kegiatan usahataninya.

\section{Pertimbangan Petani Menentukan Jenis Komoditi Pada Lahan Tegalan}

Kondisi ketidakpastaian pada lahan tegalan yang berbeda dengan kondisi lahan sawah, tentu akan mempengaruhi pertimbangan petani dalam menentukan jenis komoditi yang akan ditanamnya. Jenis komoditi yang ditanam petani pada lahan tegalan di daerah penelitian sangat beragam dan bersifta kontinyu. Beberapa petani melakukan perubahan atau pergiliran jenis komoditi yang di tanam pada setiap musim tanam. Pergiliran tersebut tentu sangat dipengaruhi keputusan petani dengan mempertimbangan berbagai aspek ketidakpastian. Adapun aspek ketidakpastian yang menjadi bertimbangan petani dalam menentukan jenis komoditi yang akan ditanam pada setiap musim tanam dapat dilihat pada Tabel 8 .

Tabel 8 Pertimbangan Petani Dalam Menentukan Jenis Komoditi Pada Setiap Musim Tanam Pada Lahan Tegalan

\begin{tabular}{|c|c|c|}
\hline $\begin{array}{l}\text { Pertimbangan Petani dalam Menentuan Jenis Komoditi Pada Musim } \\
\text { Tanam Ke } 1\end{array}$ & Frekuensi & $\begin{array}{l}\text { Persentase } \\
\quad(\%)\end{array}$ \\
\hline $\begin{array}{l}\text { Harga jual tinggi, menyesuaikan kondisi cuaca, merasa cocok dengan } \\
\text { lahan dan air, mudah mendapatkan bibit, sudah turun temurun/ } \\
\text { kebiasaan }\end{array}$ & 14 & 23,3 \\
\hline $\begin{array}{l}\text { Menyesuaikan kondisi cuaca, merasa cocok dengan kondisi lahan dan } \\
\text { air, mudah mendapatkan bibit }\end{array}$ & 1 & 1,7 \\
\hline Sudah turuntemurun/kebiasaan & 9 & 15,0 \\
\hline $\begin{array}{l}\text { Harga jual tinggi, hasil tinggi, menyesuaikan kondisi cuaca, merasa } \\
\text { cocok dengan kondisi lahan dan air, mudah mendapatkan bibitnya }\end{array}$ & 11 & 18,3 \\
\hline $\begin{array}{l}\text { Harga jual tinggi, hasil produksi tinggi, menyesuaikan kondisi cuaca, } \\
\text { merasa cocok dengan kondisi lahan dan air, mudah mendapatkan bibit, } \\
\text { mengikuti petani lain }\end{array}$ & 1 & 1,7 \\
\hline $\begin{array}{l}\text { Menyesuaikan kondisi cuaca, merasa cocok dengan kondisi lahan dan } \\
\text { air, sudah turun temurun/kebiasaan, mengikuti petani lain }\end{array}$ & 10 & 16,7 \\
\hline Harga jual tinggi, hasil produksi tinggi, sudah turun temurun/kebiasaan & 1 & 1,7 \\
\hline $\begin{array}{l}\text { Harga jual tinggi, menyesuaikan kondisi cuaca, merasa cocok dengan } \\
\text { kondisi lahan dan air, mudah mendapatkan bibit, sudah turun temurun/ } \\
\text { kebiasaan }\end{array}$ & 1 & 1,7 \\
\hline Harga jual tinggi, mudah menjual hasilnya, hasil produksi tinggi & 10 & 16,7 \\
\hline $\begin{array}{l}\text { Harga jual tinggi, hasil produksi tinggi, menyesuaikan kondisi cuaca, } \\
\text { merasa cocok dengan kondisi lahan dan air, mudah mendapatkan bibit }\end{array}$ & 2 & 3,3 \\
\hline Jumlah & 60 & 100,0 \\
\hline
\end{tabular}


Pertimbangan Petani dalam Menentuan Jenis Komoditi Pada Musim Tanam Ke 2

\section{Frekuensi Persentase}

Harga jual tinggi, mudah menjualnya, hasil produksi tinggi, menyesuaikan kondisi cuaca, merasa cocok dengan kondisi lahan dan air, mudah mendapatkan bibit, mengikuti petani lain

Sudah turun temurun/kebiasaan

Harga jual tinggi, mudah menjualnya, hasil produksi tinggi, menyesuaikan kondisi cuaca, merasa cocok dengan kondisi lahan dan air, mudah mendapatkan bibit

Harga jual tinggi, hasil produksi tinggi, menyesuaikan kondisi cuaca, merasa cocok dengan kondisi lahan dan air, mudah mendapatkan bibit, mengikuti petani lain

Menyesuaikan kondisi cuaca, merasa cocok dengan kondisi lahan dan air, sudah turun temurun, mengikuti petani lain

Total

Pertimbangan Petani dalam Menentuan Jenis Komoditi Pada Musim Tanam Ke 3

Harga jual tinggi, mudah menjualnya, hasil produksi tinggi, menyesuaikan kondisi cuaca, merasa cocok dengan kondisi lahan dan air, mudah mendapatkan bibit, mengikuti petani lain

Sudah turun temurun/kebiasaan

9

16

Harga jual tinggi, hasil tinggi, menyesuaikan cuaca, merasa cocok

100,0

\section{Frekuensi Persentase} dengan kondisi lahan dan air, mudah mendapatkan bibit, mengikuti petani lain

Hasil produksi tinggi, menyesuaikan kondisi cuaca, merasa cocok dengan kondisi lahan dan air, sudah turun temurun/kebiasaan, mengikuti petani lain

Menyesuaikan kondisi cuaca, merasa cocok dengan kondisi lahan dan air, sudah turun temurun/kebiasaan, mengikuti petani lain

Harga jual tinggi, hasil produksi tinggi, sudah turun temurun/kebiasan

Harga jual tinggi, menyesuaikan kondisi cuaca, merasa cocok dengan kondisi lahan dan air, mudah mendapatkan bibit, sudah turun temurun/ kebiasaan

Harga jual tinggi, mudah menjualnya, hasil produksi tinggi

Menyesuaikan kondisi cuaca, merasa cocok dengan kondisi lahan dan air, sudah tutun temurun/kebiasaan

1

Total
8,3 100,0

Sumber: Data Primer, 2017

Hasil penelitian sebagaimana tercantum pada Tabel 8 menunjukkan adanya variasi pertimbangan petani dalam menentukan jenis kemoditi yang akan ditanam pada musim tanam ke 1, ke 2 maupun ke 3 . Pada musim tanam ke 1 pertimbangan petani yang paling dominan adalah karena harga jual selalu tinggi, menyesuaikan dengan kondisi cuaca, merasa cocok dengan kondisi lahan dan air, kemudahan mendapatkan bibit dan sudah merupakan turun temurun/kebiasaan, kemudian diikuti dengan pertimbangan karena harga jual tinggi, hasil produksinya tinggi, menyesuaikan kondisi cuaca dan kemudahan mendapatkan bibitnya, menyesuaikan kondisi cuaca, sudah turun temurun/ kebiasaan, mengikuti petani lain dan karena harga jual tinggi, mudah menjual hasilnya, hasil produksi tinggi, sedangkan pertimbangan yang lainnya relatif kurang dari 5\%.

Pada musim tanam ke 2 seperti yang tampak pada Tabel 8 pertimbangan yang paling dominan adalah karena harga jual tinggi, mudah menjual hasilnya, hasil produksi tinggi, menyesuaikan kondisi cuaca, merasa cocok dengan kondisi lahan dan air, mudah mndapatkan bibit dan mengikuti petani lain, kemudian disusul karena pertimbangan harga jual tinggi, mudah menjual hasilnya, hasil produksi tinggi, menyesuaikan kondisi cuaca, merasa cocok dengan kondisi lahan 
dan air serta mudah mendapatkan bibit, kemudahan karena menyesuaikan kondisi cuaca, merasa cocok dengan kondisi lahan dan air, sudah turun temurun/ kebiasaan, mengikuti petani lain, kemudian karena sudah turun-temurun/kebiasaan dan kemudian karena harga jual tinggi, hasil produksi tinggi, menyesuaikan kondisi cuaca, merasa cocok dengan kondisi lahan dan air, mudah mendapatkan bibit serta mengikuti petani lain.

Pada musim tanam ke 3 seperti yang tampak pada Tabel 8 pertimbangan petani yang paling dominan adalah karena harga jual tinggi, mudah menjual hasilnya, hasil produksi tinggi, menyesuaikan kondisi cuaca, merasa cocok dengan kondisi lahan dan air, mudah mendpatkan bibit dan mengikuti petani lain, kemudian disusul karena harga jual tinggi, hasil produksi tinggi, menyesuaikan cuaca, merasa cocok dengan kondisi lahan dan air, mudah mendapatkan bibit, mengikuti petani lain, kumudian karena sudah turun-temurun/ kebiasaan dan kumudian karena menyesuaikan kondisi cuaca, merasa cocok dengan kondisi lahan dan air, sudah turun-temurun dan mengikuti petani lain, sedangkan pertimbangan lainnya rata-rata kurang dari $10 \%$. Banyaknya variasi yang menjadi pertimbangan petani dalam menentukan jenis komoditi yang akan ditanam memberikan gambaran bahwa petani di lokasi penelitian semakin rasional dalam melakukan kegiatan usahataninya.

\section{KESIMPULAN DAN SARAN}

Jenis ketidakpastian yang sering dihadapi petani di lokasi penelitian ada dua jenis yaitu ketidakpastian yang bersifat alamiah dan yang bersifat sosial-ekonomi. Jenis ketidakpastian yang bersifat alamiah terkait dengan penurunan kesuburan lahan, perubahan curah hujan, kekeringan/kekurangan air, tanah longsor, erosi, hama dan penyakit tanaman, dan jenis variatas tanaman, sedangkan ketidakpastian yang bersifat sosialekonomi terkait dengan kasus pencurian alat pertanian/ hasil produksi, fluktuasi harga pupuk dan obat-obatan, ketersediaan modal, pembiayaan yang dinvestasikan dalam pertanian, lokasi tempat pemasaran, besaran bunga kredit/pinjaman untuk usahatani dan perubahan teknologi yang digunakan dalam pertanian.

Ketidakpastian dalam memanfaatkan lahan pertanian telah mempengaruhi petani untuk mempertimbangan jenis komoditi yang akan diusahakannya. Adapun yang menjadi pertimbangan petani dalam menentukan jenis komoditi diantaranya terkait dengan aspek sosial-ekonomi seperti; harga komoditi, kemudahan melakukan perawatan tanaman, ketersedian pupuk dan obat-obatan, biaya produksi, produksi/produktivitas dan kebiasaan yang turuntemurun, kebutuhan konsumsi subsistem dan terkait aspek fisik seperti; kondisi iklim/cuaca, kondisi lahan dan air serta hama dan penyakit tanaman.

\section{UCAPAN TERIMAKASIH}

Pada kesempatan ini penulis mengucapkan banyak terima kasih kepada Fakultas Geografi UGM yang telah memberikan dana Hibah Penelitian Dosen Tahun 2017. Penulis juga, mengucapkan banyak terima kasih kepada asisten lapangan yag telah membantu dalam mengumpukan data di lapangan.

\section{DAFTAR PUSTAKA}

Adiyoga, W. dan T. A. Soetiarso (1999). Strategi Petani Dalam Pengelolaan Resiko Pada Usahatani cabai, Jurnal Holtikultura, Vol. 8 No.4: hal 1299-1311.

Bachri Syamsul, Sugeng Utaya, Farizki Dwitri Nurdiansyah, Alif Erfika Nurjanah, Lela Wahyu Ning Tyas, Denny Setia Purnama, dan Akhmad Amri Adillah, (2017) Analisis dan Optimalisasi Potensi Lahan Pertanian sebagai Kajian Dampak Positif Erupsi Gunungapi Kelud 2014, Majalah Geografi Indonesia Vol. 31, No. 2: hal 33-43.

Barlowe, R., (1978), Land Resorce Economics. PrenticeHall, Inc., New Jersey.

Gitoasmoro, S., (1999), Prilaku Petani Dalam Pengelolaan Lahan Bonorowo Di kabupaten Lamongan (Suatu Analisis Geografi), Disertasi, Universitas Gadjah Mada, Yogyakarta.

Juarini, (2003), Prilaku Ekonomi Terhadap Resiko Usahatani di Lahan Pantai Kabupaten Kulon Progo, Jurnal Agro Ekonomi, 9 ( 2):44-56.

Kumbhakar CS. (2002). Specification and Estimation of Production Risk, Risk Preferences and Technical Efficiency. American Journal Agricultural Economic, Vo. 1 No.84:8-22.

Morgan, W.B. and Munton, R.J.C., (1971), Agricultural Geography, Methuen and Co. Ltd., London.

Mubyarto,(1986), Politik Pertanian dan Pembangunan Desa, Penerbit, Sinar Harapan, Yogyakarta.

Peter Laut,(1968), Agricultural Geography, Vol. I, Nelson, Nelbourme.

Rostam, Katiman dan Anuar Tengku, (1984), Geografi Kemanusian, Nurin Enterprise, Kuala Lumpur.

Ruthenberg, Hans, (1980), Farming System in The Tropics, Clarendon Press, Oxford.

Saefulhakim, R. Sunsun, and Lutfi, Nasoetion, (1994), Rural Land Use Management for Economic Development, Paper Presented at the Seminar on Agricultural Land Use Management, Organized by Asian Productivity Organisation (APO), Tokyo 8th-18th November 1994.

Soekartawi; Soehardjo, A.; Dillon, J.L., and Hardaker, B.J., 1986. Ilmu Usaha-tani dan Penelitian untuk Pengembangan Petani Kecil. UI Press, Jakarta,

Soekartawi, Rusmadi dan E. Damaijati.,1993. Resiko dan ketidakpastian dalam Agribisnis. Manajemen PT Raja Grafindo, Jakarta 
Soemihardjo, (1991), Penanganan Lahan Kritis dari Masa Ke masa, Makalahan: Lokakarya dan Seminar Perencanaan, Pelaksanaan, Pelaksanaan dan Pemanfaatan Lahan, STPN, Yogyakarta.

Sudrajat, (2016), Bahan Ajar Geografi Pertanian, Fakultas Geografi UGM, Yogykarta.

Suparmoko, M., (1995), Ekonomi Sumberdaya Alam dan Lingkungan, Penerbit BPFE-UGM, Yogyakarta.

Symons, L., (1966), Agricultural Geography, Bell, London, But the Geography of Word Agriculture is Reviewed in Most Ecnomic Geography Texst; e.g.

Watters, A., and Bayer, (2003), Farming Sustainability and Decision Making In Pananao SierraDominica, Journal Effah, 6 (2) : 87-111. 